\title{
MENGEMBANGKAN PENDIDIKAN KARAKTER CALON GURU SEJARAH MELALUI LESSON STUDY
}

\author{
Bobi Hidayat \\ Pendidikan Sejarah FKIP Universitas Muhammadiyah Metro \\ Email: hidayat_bobi@yahoo.com
}

\begin{abstract}
Abstrak
Penguasaan pendidikan karakter guru sejarah dalam pembelajaran perlu ditanamkan sejak guru sejarah menempuh pendidikan di Perguruan Tinggi. Salah satu wahana yang dapat diterapkan adalah dengan menjalankan model lesson study dalam proses pembelajaran bagi mahasiswa baik saat pembelajaran micro maupun saat mahasiswa calon guru sejarah praktik mengajar di sekolah. Pembelajaran menggunakan model lesson study mencakup tiga tahapan yaitu: 1) Tahap Perencanaan (Plan), 2) Tahap Pelaksanaan (Do), 3) Tahap Pengamatan (observasi) dan Refleksi (See). Model lesson study merupakan pengelolaan pembelajaran yang bersifat terbuka. Melalui model lesson study yang dirancang dengan baik akan dapat melatih calon guru sejarah memiliki pendidikan karakter guru seperti jujur, disiplin, peduli terhadap orang lain, percaya diri, kretaif, terbuka dan sabar.
\end{abstract}

Kata Kunci: Pendidikan Karakter, Guru Sejarah, Lesson Study

\section{Abstract}

The mastering of character building for teaching learning history must be applied since the history teacher were learning in university. One of the mode that can be used is applying lesson study model in learning process whether in micro teaching or when the history students get teaching practice in school. There are three things that includes in teaching learning uses lesson study model, there are: plan, do, observation and see. Lesson study model is opened teaching learning process. Through good lesson study design, the history teacher candidate can be trained in having good teaher character building such as honest, discipline, care to other people, confidence, creative, overt and patient.

Keywords: Character Building, History Teacher, Lesson Study

\section{Pendahuluan}

Pendidikan tidak terlepas dari tugasnya yang salah satunya adalah penanaman hingga pembentukan karakter peserta didik. Karakter atau watak adalah suatu sifat yang tampak dari prilaku sehari-hari sebagai pengaruh dari lingkungan, sifatnya tidak permanen (Nurrohman, 2011). Pengertian ini mengarah pada prilaku yang muncul sehari-hari dalam diri seseorang. Sifat prilaku ini tidak permanen dan dapat berubah-ubah sesuai dengan pengaruh lingkungan di sekitarnya. Karakter seseorang merupakan sifat alami seseorang dalam merespon situasi secara bermoral, yang diwujudkan dalam tidakan nyata melalui prilaku baik, jujur, ikhlas, bertanggungjawab, dan hormat terhadap orang lain (Mulyasa, 2012). Orang berkarakter, prilaku baiknya tidak dibuat-buat melainkan alami muncul dari diri seseorang ketika harus menyikapi suatu keadaan. Keadaan ini 
yang seharusnya juga ada dalam diri peserta didik. Salah satu wahana untuk mendapatkan karakter yang alamiah ada dalam diri peserta didik adalah melalui proses pembelajaran yang didisain dengan baik oleh guru, dan ini menjadi salah satu tugas yang harus dilaksanakan oleh seorang guru di sekolah.

Tugas guru ini dapat berhasil diwujudkan jika diimbangi dengan teladan yang baik dari pendidiknya. Guru merupakan sentral berhasil atau tidaknya pendidikan karakter tertanam dalam diri peserta didik, karena guru akan menjadi contoh prilaku bagi perserta didik. Hal ini senada dengan pendapat Handoko (Prosiding Semnas, 2012) yang mengemukakan bahwa peran guru merupakan titik sentral dalam proses belajar pembelajaran, guru akan menjadi panutan dan tuntunan siswanya. Semua prilaku dan sikap guru akan menjadi model bagi siswanya. Pengertian ini mengarah pada pentingya pendidikan karakter yang juga harus dimiliki oleh seorang guru dimana karakter ilmiah yang muncul tidak dapat ditanamkan secara cepat atau instan. Karakter guru/dosen tidak datang tibatiba tapi harus dibina secara terus menerus/berkelanjutan sejak pendidikan guru (Sumar, 2012).

Melihat kondisi seperti ini, menuntut bahwa pendidikan karakter juga harus mulai ditanamkan sejak dini yaitu saat guru dididik menjadi calon guru di Perguruan Tinggi. Pendidikan karakter guru perlu ditanamkan sejak dini dikarenakan karakter guru tidak serta merta muncul pada diri pendidik saat menjadi seorang guru, melainkan harus melalui proses penanaman karakter guru yang dilakukan secara berkesinambungan.

Begitu juga dengan pendidikan karakter guru sejarah. Calon guru sejarah perlu dikenalkan bahkan dituntut untuk memiliki karakter pendidik yang baik agar tidak salah dalam mendidik siswa di sekolah. Guru sejarah yang berkarakter akan mampu menanamkan nilai-nilai yang terdapat dalam materi sejarah pada peserta didik. Begitu juga sebaliknya, guru sejarah yang tidak berkarakter pendidik akan sulit menanamkan nilai-nilai karakter pada peserta didik, bahkan bisajadi akan menjadi masalah dalam proses pendidikan di sekolah.

Pendidikan di sekolah dapat bermasalah jika lulusan yang dihasilkan tidak memiliki karakter yang baik. Masnur (2012) berpendapat bahwa salah satu kesalahan fatal adalah pendidikan tanpa karakter, kecerdasan plus karakter itu adalah tujuan akhir dari pendidikan; mendidik seseorang dalam aspek kecerdasan otak dan bukan aspek moral adalah ancaman marabahaya dalam masyarakat. Pengertian ini 
mengarah pada pentingnya pendidikan karakter yang harus dimiliki oleh peserta didik. Melalui guru yang berkarakter diharapkan peserta didik yang dihasilkan juga memiliki karakter yang baik sehingga tidak membahayakan masyarakat disekitarnya.

Menurut Sumar (2012) guru dan dosen yang berkarakter hendaknya memiliki sifat inofatif, objektif, peduli dengan masa depan siswa, ikhlas, peka dan perhatian serta kasih sayang kepada siswa. Untuk memiliki karakter seperti ini perlu ada upaya yang dilakukan oleh guru terutama dalam proses pembelajaran. Begitu juga dengan guru sejarah, guru sejarah dituntut memiliki kemampuan dalam mengelola proses pembelajaran dengan baik selain pengetahuan materi historisnya. S.K. Kochhar (2008:393-394) berpendapat bahwa setiap guru sejarah harus memperluas pengetahuan historisnya dengan menguasai beberapa pengetahuan dasar untuk memperkuat pembelajaran sejarah. Pengertian ini merujuk pada tuntutan guru sejarah yang tidak hanya mengetahui tentang materi sejarah akan tetapi juga harus berinovasi terhadap model-model pembelajaran sejarah.

Inovasi model pembelajaran yang dapat dilakukan salah satunya adalah penerapan model Lesson Study. Model ini juga dapat dilaksanakan atau dikenalkan dalam proses pembelajaran micro atau pada saat mahasiswa praktik pembelajaran di sekolah bersama teman sejawat.

Lesson Study adalah model pembinaan profesi pendidik melalui pengkajian pembelajaran secara kolaboratif dan berkelanjutan berlandaskan prinsip-prinsip kolegialitas dan mutual learning untuk membangun karakter guru dan dosen (Sumar, 2012). Pengertian ini merujuk pada pengelolaan proses pembelajaran secara kelompok yang melibatkan kolega atau teman sejawat untuk saling berbagi pengalaman dan saling memberi saran untuk kebaikan proses pembelajaran bersama. Pembinaan profesi ini dilakukan secara berkesinambungan dengan tujuan agar pendidikan karakter yang ingin ditanamkan pada guru dapat terwujud. Pembinaan profesi ini juga dapat dilakukan untuk kalangan calon guru terutama calon guru sejarah yang sedang menempuh pendidikan di perguruan tinggi kependidikan.

Lesson Study tidak hanya memperhatikan pembelajaran untuk satu pertemuan atau satu pokok bahasan akan tetapi bagaimana membelajarkan satu unit materi pokok dan bidang studi serta memperhatikan perkembangan siswa dalam jangka panjang (Lewis dalam Susilo, 2011:11). Berdasarkan pendapat tersebut lesson 
study lebih menekankan pada penguasaan materi oleh siswa. Guru dituntut bersama kolega agar terus memperhatikan kemampuan dan perkembangan belajar siswa. Bahkan guru bersama kolega akan dapat mengidentifikasi sejauh mana penguasaan materi oleh siswa di kelas (Kuswono, 2017: 163-172).

Penguasaan model lesson studi dan pendidikan karakter dapat dimulai pada saat calon guru dididik di perguruan tinggi. Begitu pula pada mahasiswa program studi pendidikan sejarah. Calon guru sejarah harus memiliki kompetensi yang mumpuni disegala bidang sehingga dapat bersaing dunia kerja. Hal ini dikerenakan guru sejarah harus lengkap dari segi akademis. Tidak hanya sekedar mengetahui tentang pengetahuan sejarah akan tetapi perlu ada inovasi model pembelajaran sejarah serta kepemilikan karakter pendidik yang baik. Sehingga dalam upaya pemenuhan tuntutan itu, menanamkan pendidikan karakter guru sejarah harus sudah di mulai sejak menjadi calon guru sejarah di perguruan tinggi dengan diperkenalkan model pembelajaran yang salah satunya model lesson study.

\section{Metode Kajian}

Kajian ini menggunakan metode kajian kualitatif deskriptif. Metode ini merupakan hasil gagasan dari penulis yang kemudian dikembangkan berdasarkan teori-teori sesuai dengan variabel penelitian.

Kajian ini bertujuan agar dapat membantu calon pendidik khususnya calon guru sejarah untuk mengembangkan pendidikan karakter yang harus dimiliki oleh calon pendidik sebagai bekal ketika menjadi seorang guru. Selain itu, implementasi model lesson study pada calon guru sejarah pada tulisan ini juga bertujuan untuk membekali calon guru sejarah akan wahana yang dapat digunakan untuk mengembangkan proses pembelajaran yang dilakukan di sekolah agar lebih bermakna dan mudah dalam mencapai tujuan belajar.

\section{Hasil dan Pembahasan}

Profesi guru identik dengan kecenderungan mengelola proses pembelajaran di kelas. Guru adalah pendidik profesional dengan tugas utama mendidik, mengajar, membimbing, mengarahkan, melatih, menilai, dan mengevaluasi peserta didik pada pendidikan anak usia dini jalur pendidikan formal, pendidikan dasar, dan pendidikan menengah (UU RI No 14 tahun 2015, BAB 1, pasal 1). Berdasarkan pengertian tersebut maka sangat jelas bahwa tugas guru yang utama adalah mengelola proses pembelajaran dari awal sampai akhir, bahkan sampai sesudah proses pembelajaran yaitu mengevaluasinya. 
Selain itu, guru juga bertugas mendidik anak melalui penanaman nilai-nilai yang baik kepada peserta didik. Untuk menjalankan tugas tersebut maka guru harus memiliki wawasan yang luas dengan cara melakukan pengembangan diri baik secara mandiri maupun secara kelompok.

Pelaksanaan pembelajaran oleh guru, terutama guru sejarah tidak hanya sebatas mengelola proses pembelajaran, akan tetapi juga sampai menanamkan karakter pada peserta didik. Oleh karenanya guru sejarah harus memiliki karakter yang baik terlebih dahulu agar dapat mengimplementasikanya dalam proses pembelajaran karena dapat menjadi contoh bagi siswanya.

Guru sejarah tidak terlepas dari bagaimana guru sejarah itu mendapat pendidikan di perguruan tinggi. Calon guru sejarah perlu dikembangkan karakternya. Salah satu jalan yang dapat ditempuh adalah dengan mengimplementasikan model lesson study.

Lesson study menurut Susilo (2011:35) memiliki tiga tahap yaitu: 1) Tahap Perencanaan (Plan), 2) Tahap Pelaksanaan (Do), 3) Tahap Pengamatan dan Refleksi (See). Lesson study juga mengenal istilah guru model yaitu guru yang menjadi model dalam pembelajaran.
Plan dilakukan dengan tujuan agar dapat menghasilkan rancangan pembelajaran yang baik dan seideal mungkin. Hal ini dapat tercapai karena dalam tahap perencanaan (plan) calon guru melakukan dengan teman sejawat, tidak sendiri. Tahap ini mencakup semua unsur-unsur yang diperlukan dalam proses pembelajaran, semisal Lembar kerja siswa (LKS) yang didisain, metode pembelajaran, media pembelajaran yang dibutuhkan dan keperluan pembelajaran yang lainya. Hal ini dilakukan agar dalam proses pembelajaran di kelas dapat berjalan dengan baik dan dapat mengakomodir kebutuhan setiap siswa di kelas.

Tahapan selanjutnya adalah Do. Tahapan ini merupakan tahapan pelaksanaan pembelajaran. Tahapan implementasi perencanaan yang telah di susun bersama. Pelaksanaan proses pembelajaran di kelas juga disertai oleh tim yang ikut menyusun rencana pembelajaran sebagai observer. Hal ini dilakukan dengan tujuan agar permasalahan yang muncul di kelas saat pembelajaran dapat menjadi dasar evaluasi saat melaksanaan tahapan selanjutnya. Pada tahapan ini, observer dibekali lembar observasi dan tidak boleh menggangu proses pembelajaran yang dilaksankan. Observer fokus memperhatikan siswa yang menjadi target tujuan pembelajaran. 
Tahapan yang terakhir adalah See. Tahapan ini bertujuan untuk mendiskusikan hasil dari proses pembelajaran yang telah dilaksanakan oleh guru model di kelas. Bersama teman sejawat yang ikut dalam proses pembelajaran di kelas sebagai observer akan membahas apakah masih terdapat siswa yang kurang menguasai materi pembelajaran atau tidak. Hasil dari see akan dijadikan dasar merencanakan proses pembelajaran selanjutnya. Hal ini dilakukan terus menerus hingga proses pembelajaran yang ideal tercapai.

Pelaksanaan pembelajaran yang sesuai dengan tahapan Lesson study dapat dilakukan oleh semua guru bidang studi termasuk guru bidang studi sejarah. Guru Sejarah diharapkan memilki keterbukaan dalam mengelola proses pembelajaran. Memang awalnya sulit untuk dilakukan karena harus melibatkan teman sejawat, menentukan kesepakatan waktu dll. Namun jika sudah terbiasa maka akan mudah dan sangat membantu guru dalam mencapai tujuan pembelajaran yang diinginkan.

Begitu pula calon guru sejarah, pelibatan teman sejawat dalam mengelola proses pembelajaran akan menambah wawasan calon guru sejarah. Selain itu juga dapat dijadikan wahana untuk mengembangkan karakter pendidik bagi calon guru sejarah. Ada beberapa karakter pendidik bagi calon guru sejarah yang didapat dari proses pembelajaran menggunakan tahapan Lesson study terutama dalam mengelola pembelajaran sejarah di kelas kecil saat pembelajaran micro atau saat praktik pembelajaran di sekolah, antara lain:

1. Jujur. Karakter ini sulit di peroleh saat calon guru sejarah melakukan pembelajaran secara mandiri. Kecenderungan untuk tidak jujur sangat tinggi karena merasa tidak ada yang mengawasi. Melalui pembelajaran yang terbuka menggunakan model Lesson study, maka guru akan dapat jujur dan melatih kejujuran apapun hasil dari proses pembelajaran yang diperoleh. Calon guru akan sulit memanipulasi hasil pembelajaran dikarenakan ada teman sejawat sebagai observer yang ikut dalam proses pembelajaran.

2. Disiplin. Dengan adanya pembelejaran kolaboratif, yang tentu saja dapat melibatkan banyak teman sejawat sebagai observer maka kesepakatan waktu harus di taati. Calon guru sejarah akan disiplin datang tepat waktu dalam proses pembelajaran sebagai bentuk menjalankan kesepakatan waktu. Calon guru sejarah akan lebih menghargai waktu, kebiasaan calon guru untuk menunda-nunda waktu masuk kelas, atau melaksanakan 
proses pembelajaran menjadi tidak bisa dilakukan karena akan menunjukkan kepribadian calon guru tersebut.

3. Peduli dengan orang lain. Karakter pendidik yang seperti ini sulit dilakukan. Kebiasan guru yang acuh sering kali tertanam dan mendarah daging dalam diri guru sehingga kepedulian terhadap siswa menjadi kurang. Terkadang guru juga pilih kasih memberikan perhatian pada siswanya. Melalui pembelajaran Lesson study maka guru akan lebih peduli pada semua siswa. Hal ini dikarenakan tujuan pembelajaran yang harus di capai bukan tertuju pada beberapa siswa, akan tetapi pada semua peserta didik. Sehingga guru akan selalu berupaya memberikan perhatian kepada semua peserta didik agar masingmasing dapat mencapai tujuan pembelajaran yang dilaksanakan. Karakter inilah yang mulai dikembangkan pada saat calon guru sejarah belajar di perguruan tinggi.

4. Percaya diri. Calon guru sejarah harus memiliki kepercayaan diri yang tinggi dalam mengelola proses pembelajaran di kelas. Melalui Lesson study calon guru sejarah di latih untuk memiliki kepercayaan diri yang tinggi. Hal ini dikarenakan pembelajaran yang dilaksanakan tidak hanya antara guru dan siswa, akan tetapi juga ada guru lain yang menjadi observer. Keberadaan observer sedikit banyak akan berpengaruh pada kualitas kepercayaan diri guru dalam menjalankan proses pembelajaran.

5. Kreatif. Calon guru sejarah hendaknya kreatif dalam mengelola proses pembelajaran sejarah di kelas. Agar proses pembelajaran tidak membosankan siswa, maka calon guru sejarah dilatih untuk memvariasikan proses pembelajaran sejarah. Model Lesson study akan mendorong calon guru sejarah untuk kreatif. Jika calon guru sejarah hendak akan menjadi guru model, maka guru model akan berfikir kreatif tentang strategi pembelajaran apa yang akan digunakan. Rancangan awal pembelajaran akan dibawa dalam proses plan bersama rekan sejawat. Berbeda jika proses pembelajaran dilakukan secara mandiri, guru berkecenderungan kurang kreatif serta monoton dalam proses pembelajaranya.

6. Terbuka dan sabar. Model Lesson study merupakan pembelajaran yang terbuka. Pembelajaran lesson study dilakukan dengan tujuan agar mahasiswa dapat belajar mengelola proses pembelajaran sejarah secara terbuka dan dapat saling memberikan masukan satu dengan 
yang lainya sebagai bentuk perbaikan (Bobi,2016). Hal ini tentu akan melatih calon guru sejarah untuk terbuka menerima masukan dari teman sejawat. Selain itu, tentu juga akan melatih kesabaran calon guru sejarah. Mengapa demikian? hal ini dikarenakan dalam menerima masukan dari teman sejawat pada saat refleksi yang selanjutnya akan berdampak pada melakukan revisi rancana pembelajaran yang telah dibuat. Tujuan revisi adalah untuk memperbaiki pelaksanaan proses pembelajaran berikutnya.

Pendidikan karakter calon guru dapat diperoleh dari beberapa kegiatan yang ada dalam pelaksanaan lesson study. Ali (2009) berpendapat bahwa melalui kegiatan diskusi, baik dalam kegiatan persiapan, penyamaan persepsi tentang lesson study, penentuan materi pokok, pemilihan metode dan media, maupun pada tahap refleksi, setiap guru di tuntut belajar berbagi pendapat, membuat kesepakatan, dan sekaligus menghormati kesepakatan tersebut. Hal ini juga dapat terjadi pada calon guru sejarah yang menerapkan model lesson study. Melalui kegiatan ini jika dirancang dengan baik, calon guru sejarah secara tidak langusng akan mengembangkan kemampuan pedagogiknya yang juga sekaligus akan berdampak pada kepribadian calon guru sejarah yang baik.

Dengan adanya model lesson study yang dirancang dengan baik, dan dapat diimplementasikan dengan baik oleh calon guru sejarah, maka diharapkan akan muncul guru sejarah yang berkarakter baik dan professional. Guru sejarah yang berkarakter baik dan professional akan lebih mudah mengelola proses pembelajaran di kelas serta dapat mengubah kesan belajar sejarah yang membosankan menjadi belajar sejarah yang menyenangkan.

\section{Simpulan}

Berdasarkan hasil kajian di atas, dapat disimpulkan bahwa model Lesson study yang dirancang dengan baik dapat mengembangkan pendidikan karakter calon guru sejarah. Model Lesson study yang bersifat terbuka akan dapat melatih guru/calon guru sejarah untuk mengembangkan kepribadianya seperti jujur, disiplin, peduli terhadap orang lain, percaya diri, kretaif, terbuka dan sabar.

\section{Daftar Pustaka}

Ali Mahmudi. Mengembangkan Kompetensi Guru Melalui Lesson Study. Jurnal Forum Kependidikan FKIP UNSRI. Volume 28, Nomor 2, Maret 2009

Bobi Hidayat. Analisis Keterlaksanaan Program Perkuliahan Micro teaching berbasis lesson study di Program Studi Pendidikan 
Sejarah FKIP UM Metro. Historia. Volume 4, Nomor 2, Tahun 2016.FKIP UM Metro

Handoko Santoso. (2012). Prosiding Seminar Nasional "Membangun Karakter Guru dan Dosen untuk Mewujudkan Pendidikan Berkarakter. Metro. UPT PPL UM Metro

Masnur Muslich. (2012). Pendidikan Karakter "Menjawab Tantangan Krisis multidimensional". Jakarka. Bumi Aksara

H.E. Mulyasa. (2012). Manajemen Pendidikan Karakter. Jakarta. Bumi Aksara

Kuswono, K. (2017). Implementation of Learning History Based on Lesson Study. Historia: Jurnal Pembelajaran Sejarah dan Sejarah UM Metro, 5(2), 163172.

Nurrohman Hajam. (2011). Pendidikan Karakter. Meteri pada Pertemuan dan Seminar Nasional LPTK Muhammadiyah di Babel.

S.K.Kochhar. (2008). Pembelajaran Sejarah"Teaching of History". Jakarta. PT Gramedia Widiasarana Indonesia

Sumar Hendayana. (2012). Pengembangan Karakter Guru dan Dosen Melalui Lesson Study. Materi pada Seminar nasional Pendidikan di UM Metro

Susilo dkk. (2011). Lesson Study Berbasis Sekolah. Malang. Bayumedia Publishing

Tim Penyusun. (2006). Undang-undang RI Nomor 14 tahun 2005 "tentang Guru dan Dosen”. Bandung. Fokusmedia 
Mengembangkan Pendidikan Karakter Calon Guru Sejarah melalui..., Bobi Hidayat, 151- 160 